\title{
MANAJEMEN PEMBIAYAAN PENDIDIKAN (ANALISIS KONSEP DAN IMPLIKASINYA TERHADAP PENINGKATAN MUTU PENDIDIKAN)
}

\author{
Mesiono, Haidir
}

Universitas Islam Negeri Sumatera Utara Medan, Universitas Muslim Nusantara Al-Washliyah Medan Jl. Willem Iskandar Pasar V Medan Estate, Kota Medan, Sumatera Utara e-mail: mesiono@uinsu.ac.id, haidir@umnaw.ac.id

\begin{abstract}
Abstrak: Penelitian ini bertujuan untuk menganalisis konsep dasar pembiayaan pendidikan dan implikasinya terhadap peningkatan mutu pendidikan. Penelitian ini menggunakan metode library research. Hasil penelitian menunjukkan bahwa peningkatan mutu suatu lembaga / lembaga pendidikan merupakan harapan dan keinginan masyarakat pengguna jasa pendidikan. Oleh karena itu, untuk mewujudkan hal tersebut, berbagai upaya strategis telah dilakukan oleh pemerintah dan masyarakat selaku pengelola dan pemangku kepentingan pendidikan. Diantaranya, yang dilakukan pemerintah adalah merancang standar nasional pendidikan. Berdasarkan Undang-Undang Sistem Pendidikan Nasional Nomor 20 Tahun 2003 terdapat 8 standar nasional yang bertujuan untuk meningkatkan mutu suatu lembaga pendidikan. Berdasarkan peraturan pemerintah, salah satu dari delapan standar nasional pendidikan adalah standar pembiayaan. Pembiayaan pendidikan merupakan hal terpenting dan tidak terpisahkan dalam kegiatan pengelolaan pendidikan. Jadi, antara lain, kebijakan pemerintah adalah dengan menggulirkan dana BOS di tingkat sekolah. Pembiayaan pendidikan dan pendanaan yang dikelola sekolah / madrasah harus transparan agar tercipta akuntabilitas. Jika dapat dipertanggungjawabkan maka kredibilitas lembaga pendidikan tersebut akan meningkat. Jika kredibel maka dengan sendirinya akan meningkatkan kualitas institusi pendidikan. Untuk mencapai hal tersebut, pemerintah mengatur tentang standar pembiayaan berjangka.
\end{abstract}

Kata Kunci: Pembiayaan Pendidikan, Mutu Pendidikan, Institutusi Pendidikan

\begin{abstract}
This study aims to analyze the basic concepts of education financing and its implications for improving the quality of education. This research uses the Library Research method. The results showed that improving the quality of an educational institution / institution is the hope and desire of the community who use educational services. Therefore, to make this happen, various strategic efforts have been made by the government and the community as managers and education stakeholders. Among them, what the government is doing is designing national education standards. Based on the law national education system Number. 20 of 2003 there are 8 national standards, which aim to improve the quality of an educational institution. Based on government regulations, one of the eight national education standards is a financing standard. Education financing is the most important and inseparable thing in education management activities. So, among other things, the government policy is to roll out BOS funds at the school level If it is accountable, it will increase the credibility of the educational institution. If it is credible, it will automatically improve the quality of the educational institution.
\end{abstract}

Keywords: Education Financing, Quality of Education, Educational Institutions 


\section{PENDAHULUAN}

Pendidikan merupakan hal terpenting dalam rangka mewujudkan sumber daya manusia (SDM) yang unggul dan bermutu (berkualitas). Karenanya untuk mewujudkan hal tersebut dibutuhkan proses dan out put pendidikan yang benar-benar bermutu/berkualitas juga. Diupayakan berbagai pihak secara bersama-sama bersinergi untuk bertanggung jawab dalam meningkatkan mutu pendidikan tersebut, mulai dari pemerintah, pengelola pendidikan, para stakeholders pendidikan, dan lain sebagainya. Kesemuanya itu harus bersinergi secara bersama-sama untuk peningkatan mutu pendidikan tersebut.

Karena harapannya pengelolaan pendidikan di tengah masyarakat harus secara terus menerus secara berkelanjutan melakukan pembenahan dan melakukan berbagai inovasi agar dapat disesuaikan dengan perkembangan zaman dan kebutuhan masyarakat. Kesemuanya ini dilakukan dalam rangka mewujudkan peningkatan mutu dalam sebuah pengelolaan pendidikan baik pada pendidikan formal maupun non formal dengan berbagai jenis pendidikan mulai dari TK sampai dengan PT.

Dengan demikian, ketika kita membicarakan tentang upaya pencapaian peningkatan mutu dalam bidang pendidikan maka hal ini menjadi sebuah topik yang tak pernah habis-habisnya untuk dibahas, didiskusikan, dan bahkan diteliti. Sehingga pembahasan peningkatan mutu ini tetap menjadi sebuah isu yang aktual. Hal ini sebenarnya mengindikasikan bahwa peningkatan mutu merupakan hal terpenting dan sebuah ikon yang harus diraih dalam kegiatan pengelolaan pendidikan, dan bahkan menjadi sebuah harapan dan keinginan masyarakat pengguna jasa pendidikan Karenanya dalam peningkatan mutu sebuah lembaga pendidikan dibutuhkan berbagai macam upaya dan strategi.

Upaya dan strategi yang dilakukan pemerintah untuk menyahuti konsep peningkatan mutu pendidikan adalah dengan menerbitkannya peraturan dan perundang-undangan, diantaranya UUSPN Nomor 20 tahun 2003 tentang sietem pendidikan nasional. Bahkan di dalam UU tersebut disebutkan 6 kali katakata mutu. Hal ini menunjukkan betapa urgennyalah peningkatan mutu dalam sebuah institusi pendidikan. Selain itu juga terdapat dalam GBHN ada disebutkan istilah mutu. Hal ini sebagaimana disebutkan "Perwujudan sistem pendidikan nasional yang demokratis dan bermutu" dalam rangka mengembangkan kualitas manusia Indonesia (Alek, 2010)

Sebagai upaya dalam peningkatan mutu pendidikan, lahirlah standar mutu. Untuk mencapai standar mutu lahirlah PP No. 19 tahun 2005, dan ini merupakan penjabaran dari UU No. 20 tahun 2003 sebagaimana menurut (HAR. Tilaar, 2006) bahwa adanya delapan standar pendidikan nasional dalam menciptakan peningkatan mutu, diantaranya 1) standar isi, 2) standar proses, 3) standar kompetensi lulusan, 4) standar pendidik dan tenaga kependidikan, 5) standar sarana dan prasarana, 6) standar pengelolaan, 7) standar pembiayaan, 8) 
standar penilaian pendidikan .

Bedasarkan hal tersebut dapat dipahami, dalam upaya peningkatan mutu pendidikan pada berbagai lembaga pendidikan ada salah diantaranya yang harus terpenuhi dalam sistem pendidikan nasional menurut UU yaitu standar pembiayaan pendidikan. Standar pembiayaan pendidikan merupakan standar yang mengatur komponen dan besarnya biaya operasi satuan pendidikan yang berlaku selama satu tahun. Ada tiga macam biaya dalam standar ini, antara lain: a) biaya investasi satuan pendidikan, b) biaya personal, c) biaya operasi satuan pendidikan (Rusdiana, 2015). Ketiga macam pembiayaan pendidikan inilah yang harus dikelola secara optimal agar tercapainya peningkatan mutu di lembaga pendidikan tersebut.

Oleh karena itu, dapat dipahami dalam peningkatan mutu pendidikan mutlak dibutuhkan pembiayaan atau pendanaan dalam sebuah pengelolaan pendidikan. Karena betapa pentingnyalah pembiayaan ini, sehingga dijadikan sebagai salah satu standar nasional pendidikan. Kondisi saat ini sungguh memprihatinkan bagi lembagalembaga pendidikan yang pengelolaannya dengan standar pembiayaan yang sangat minim. Dan ditambah lagi para pengelola pendidikan tidak jujur mendistribusikan seluruh bantuan untuk pengelolaan pendidikan tersebut. Seperti adanya dana BOS yang tidak dimaksimalkan sesuai dengan standar yang berlaku, penyalahguanaan dana bantuan, dan bahkan terjadinya penyelewengan dan korupsi dana BOS yang seharusnya bisa diberdayakan secara maksimal.
Karenanya perlulah dalam pengelolaan pendidikan dibutuhkan standar nasional pendidikan yang sesuai dengan peraturan pemerintah. Satu dari delapan standar nasional pendidikan yang sangat penting adalah standar pembiayaan pendidikan. Dalam pengelolaan pendidikan, pendanaan pendidikan harus dikelola dengan baik sesuai dengan aturan dan perundang-undangan yang berlaku. Karena mustahil terjadi peningkatan mutu tanpa disupport oleh pendanaan yang cukup dan standar. Harapannya pengelolaan pembiayaan harus dilakukan secara optimal dengan menggunakan prinsip transparan dan akuntabilitas.

\section{METODE PENELITIAN}

Bahwa penelitian ini menggunakan studi literatur/kepustakaan. Penulis mengumpulkan berbagai literatur yang berkaitan dengan topik-topik tertentu yaitu tentang peningkatan mutu pendidikan dan pembiayaan pendidikan. Lalu kemudian mengumpulkannya dengan mentabulasi dari berbagai literatur baik buku maupun jurnal yang ada kaitannya dengan materi tersebut. Karenaya penelitian ini tidak menggunakan populasi dan sampel. Berdasarkan dari berbagai sumber bacaan dan pengalaman penulis tentang topik tersebu, maka penulis mendeskripsikannya menjadi sebuah laporan hasil penelitian.

\section{HASIL DAN PEMBAHASAN}

Hakikat Peningkatan Mutu Pendidikan Mutu merupakan hal terpenting 
dalam berbagai hal dan aktivitas, terutama dalam bidang pendidikan. Sehingga mutu dijadikan sebagai sebuah harapan dan dijadikan sebagai tujuan dalam berbagai aktivitas tersebut. Nah, ketika kita membicarakan tentang peningkatan mutu, terutama dalam bidang pendidikan maka hal ini menjadi sebuah topik yang trending dan tak pernah habis-habisnya untuk dikaji, dibahas, ditelaah atau diteliti dan bahkan tetap menjadi sebuah isu yang sangat hangat dan aktual. Sehingga pembicaraan ini tidak pernah habis untuk menjadi sebuah topik pembahasan sehingga kita termotivasi untuk mewujudkannya.

Hal ini menunjukkan indikasi bahwa peningkatan mutu merupakan sebuah tugas bersama dan juga sebuah ikon yang harus diraih dalam sebuah pengelolaan pendidikan. Karenanya dalam peningkatan mutu sebuah lembaga pendidikan dibutuhkan berbagai macam upaya dan strategi. Upaya dan strategi yang dilakukan dalam mewujudkan pendidikan yang bermutu tersebut harus membutuhkan kerja keras dan kerja tuntas dari berbagai unsur, baik unsur pemerintah maupun pengelola pendidikan.

Karenanya sebelum kita terlebih dahulu membahas tentang peningkatan mutu, kita terlebih dahulu memahami dan menulusuri istilah mutu. Istilah mutu dapat dipahami dan dilihat dari dua sisi, yakni dari segi normatif dan segi deskriptif (Marsus Suti, 2011). Pertama mutu dipahami dalam arti normatif, yaitu mutu ditentukan sesuai dengan pertimbangan instrinsik maupun ekstrinsik. Berdasarkan kriteria instrinsik, bahwa mutu pendidikan merupakan produk pendidikan yakni manusia yang sudah terdidik sesuai dengan standar ideal. Sedangkan berdasarkan kriteria ekstrinsik, bahwa pendidikan merupakan instrumen untuk mendidik tenaga kerja yang terdidik dan terlatih. Kedua, mutu dalam dalam arti deksriptif, yaitu mutu ditentukan berdasarkan keadaan yang sebenarnya seperti berdasarkan hasil ujian belajar siswa.

Oleh karena itu, mutu (Harvey dan Green) dalam Rivai dimaknai sebagai $a$ relative concept which changed with the context and mean different things to different people (Veitzhal Rivai, 2009). Secara teoritis, bahwa ada dua pendekatan yang dapat digunakan dalam memahami makna istilah mutu. Pertama, mutu mencerminkan sesuatu karakteristik yang dimiliki. Dalam sudut pandang ini, bahwa sesuatu yang bermutu dipandang menjadi sesuatu yang excellent/valuable dan mutu sama sekali tidak mempunyai apa yang disebut evaluative sense.

Sedangkan pendekatan kedua yang disebut pendekatan metafisik (methaphysical belief), yakni mutu dipandang sebagai sesuatu yang tidak hanya dapat dianalisis secara deskriptif, tetapi juga dapat dianalisis secara evaluatif atau sesuatu yang bisa terukur sesuai dengan standar yang berlaku. Hal ini karena dalam memandang mutu bisa dibedakan secara absolut antara faktafakta yang dikaitkan dengan analisis secara deskriptif dan nilai-nilai yang dikaitkan dengan analisis secara evaluatif.

Menurut Rivai, (Veitzhal Rivai, 2009) bahwa mutu lembaga pendidikan dapat dipahami sebagai sebuah 
pencapaian tujuan dari suatu universitas yang umumnya mencakup tri darma dari lembaga pendidikan dan pengukurannya diklakukan dengan pendekatan exceptional yang menurut Porter (1994) memiliki 3 variasi, yaitu 1) mutu sebagai sesuatu yang distinctive, 2) mutu sebagai sesuatu yang excellent, dan 3) mutu sebagai sesuatu yang memenuhi standar minimum atau conformance to standard.

Dengan demikian, bahwa mutu pendidikan merupakan derajat keunggulan dalam pengelolaan pendidikan secara efektif dan efisien untuk melahirkan keunggulan akademis dan ekstra kurikuler pada peserta didik (siswa) yang dinyatakan lulus untuk satu jenjang pendidikan atau menyelesaikan pembelajaran tertentu.

Menurut Koswara dan Triatna sebagaimana yang disebutkan dalam Ulpha bahwa sesungguhnya pendidikan yang dikategorisasikan bermutu adalah dapat dilihat dari 4 (empat) hal utama yaitu input, proses, output maupun outcome (Ulpha Lisni Azhari, 2016).

Input pendidikan yang bermutu maksudnya adalah bahwa sebuah lembaga pendidikan tersebut memiliki guru-guru atau tenaga pendidik yang bermutu, peserta didik (siswa) yang bermutu, keberadaan kurikulum yang bermutu, fasilitas lembaga pendidikan yang bermutu, serta didukung oleh berbagai aspek dalam penyelenggara pendidikan yang bermutu.

Proses pendidikan yang bermutu maksudnya adalah bahwa kegiatan proses pembelajaran yang berlangsung di lembaga pendidikan tersebut juga bermutu. Karenanya dalam pendidikan proses merupakan hal terpenting untuk menciptakan hasil yang optimal. Ukuran keberhasilan sebuah lembaga pendidikan ditentukan sebuah proses yang baik dan bermutu. Keberadaan proses yang bermutu biasanya sesuai dengan standar yang ditetapkan (SOP).

Output pendidikan yang bermutu maksudnya adalah para lulusan yang dihasilkan oleh lembaga pendidikan tersebut memiliki keterampilan dan kompetensi sebagaimana yang disyaratkan oleh standar nasional pendidikan (SNP). Output pendidikan juga merupakan kinerja yang dihasilkan oleh sebuah lembaga. Kinerja lembaga adalah prestasi lembaga yang dihasilkan dari proses/ perilaku lembaga. Kinerja lembaga dapat diukur dari kualitasnya, efektivitasnya, produktivitasnya, efisiensinya, inovasinya, kualitas kehidupan kerjanya, dan moral kerjanya. Mutu lembaga dipengaruhi oleh banyak tahapan kegiatan yang saling berhubungan (proses) seperti misalnya perencanaan, pelaksanaan, dan pengawasan (Achmad Anwar Abidin, 2017).

Sedangkan outcome pendidikan yang bermutu dimaksudkan adalah bahwa lulusan yang dihasilkan oleh lembaga pendidikan tersebut mampu melanjutkan ke jenjang pendidikan yang lebih tinggi sesuai dengan jurusannya atau terserap pada dunia usaha atau dunia industri yang memiliki daya kompetitif.

Menurut Edward Sallis dalam kutipan jurnal (Jamiludin Usman, 2016), pendidikan yang bermutu dapat 
diidentifikasi melalui ciri-ciri berikut: (1) Berfokus pada pelanggan, baik pelanggan internal maupun eksternal. (2) Berfokus pada upaya untuk mencegah masalah yang muncul, dengan komitmen untuk bekerja secara benar dari awal. (3) Memiliki investasi pada sumber daya manusianya, sehingga terhindar dari berbagai "kerusakan psikologis" yang sulit memperbaikinya. (4) Memiliki strategi untuk mencapai kualitas, baik di tingkat pimpinan, tenaga akademik, maupun tenaga administratif. (5) Mengelola atau memperlakukan keluhan sebagai umpan balik untuk mencapai kualitas dan memposisikan kesalahan sebagai instrumen untuk berbuat benar pada masa berikutnya. (6) Memiliki kebijakan dalam perencanaan untuk mencapai kualitas, baik untuk jangka pendek, jangka menengah maupun jangka panjang. (7) Memiliki proses perbaikan dengan melibatkan semua orang sesuai dengan tugas pokok, fungsi dan tanggung jawabnya. (8) Mendorong orang dipandang memiliki kreativitas, mampu menciptakan kualitas dan merangsang yang lainnya agar dapat bekerja secara berkualitas. (9) Memperjelas peran dan tanggung jawab setiap orang, termasuk kejelasan arah kerja secara vertikal dan horizontal. (10) Memiliki strategi dan kriteria evaluasi yang jelas. (11) Menempatkan kualitas yang telah dicapai sebagai jalan untuk untuk memperbaiki kualitas layanan lebih lanjut.

Memandang kualitas sebagai bagian integral dari budaya kerja. (13) Menempatkan peningkatan kualitas secara terus menerus sebagai suatu keharusan.

Selain itu pengertian mutu dapat dilihat dari dua sisi, yaitu segi normatif dan segi deskriptif. Dalam arti normatif, mutu ditentukan berdasarkan pertimbangan instrinsik dan ekstrinsik. Berdasarkan kriteria intrinsik, mutu pendidikan merupakan produk (hasil) pendidikan yakni manusia yang terdidik sesuai standar ideal. Sedangkan berdasarkan kriteria ekstrinsik, pendidikan merupakan instrumen untuk mendidik tenaga kerja yang terlatih.

Sedangkan dalam arti deksriptif, mutu ditentukan berdasarkan keadaan yang sebenarnya misalnya berdasarkan hasil ujian atau tes prestasi belajar siswa. Dengan demikian, mutu pendidikan adalah derajat keunggulan dalam pengelolaan pendidikan secara efektif dan efisien untuk melahirkan keunggulan akademis dan ekstra kurikuler pada peserta didik yang dinyatakan lulus untuk satu jenjang pendidikan atau menyelesaikan pembelajaran tertentu.

Komponen yang terkait dengan mutu pendidikan adalah pertama, kesiapan dan motivasi siswa. Kedua, kemampuan guru profesional dan kerjasama dalam organisasi sekolah. Ketiga, kurikulum meliputi relevansi isi dan operasional proses pembelajarannya. Keempat, sarana dan prasarana meliputi kecukupan dan keefektifan dalam mendukung proses pembelajaran. Kelima, partisipasi masyarakat (orang tua, pengguna lulusan dan perguruan tinggi) dalam pengembangan program-program pendidikan sekolah. 
Konsep dasar Standar Mutu Pendidikan dan pembiayaan Pendidikan

Menurut Alex bahwa mutu pendidikan (Alex, 2010) adalah berkembangnya potensi anak didik. Pendidikan dapat dikatakan berutu jika para peserta didiknya dapat mengembangkan potensi dirinya secara maksimal. Menurut Suryadi, mutu pendidikan adalah kemampuan lembagalembaga pendidikan dan satuan pendidikan dalam mengelola, dan mendayagunakan sumber-sumber pendidikan untuk menigkatkan kemampuan belajar.

Lembaga-lembaga pendidikan yang dimaksud adalah lembaga pendidikan formal dan non formal. Sehingga menurut Suryadi dalam Sam M. Chan bahwa pendidikan yang bermutu ialah dapat menghasilkan lulusan yang memiliki kemampun dasar untuk belajara sehingga dapat mengikuti bahkan menjadi pelopor dalam pembaruan dan perubahan (Alek, 2010).

Selain itu menurut Soedijarto, bahwa mutu pendidikan adalah sistem pendidikan yang dapat menghasilkan lulusan pada berbagai jenjang dan jenis yang memiliki kemampuan, nilai, dan sikap, baik kemampuan intelektual, profesional dan emosional, dan memiliki sikap jujur, berdisiplin, beretos kerja, yang tinggi, rasional, kreatif, memiliki rasa tanggung jawab kemanusiaan, kemasyarakatan dan kebangsaan, serta berakhlak mulia, beriman dan bertakwa.

Menurut Tilaar dalam Sam M. Chan bahwa pendidikan bermutu bukan hanya pendidikan yang mengembangkan intelegensi akademik tetapi perlu mengembangkan seluruh spektrum intelegensi manuisa yang meliputi berbagai aspek kebudayaan (Alek, 2010).

Hal ini juga disinkronkan dengan UUSPN Nomor 20 tahun 2003 tentang Sistem Pendidikan Nasional pasal 2, bahwa tujuan pendidikan nasional adalah untuk berkembangnya potensi peserta didik agar menjadi manuisa yang beriman kepada Tuhan Yang Maha Esa, berakhlak mulia, sehat, berilmu, cakap, kreatif, mandir, dan menjadi warga negara yang demokratis serta bertanggung jawab dalam rangka mencerdaskan kehidupan bangsa.

Oleh karena itu, standar mutu dalam pengelolaan pendidikan menjadi hal utama dan terpenting dalam sebuah pengelolaan pendidkan. Pendekatan yang perlu diperhatikan dalam peningkatan mutu pendidikan, yaitu yang pertama adalah perbaikan secara terus-menerus (continuous improvement). Konsep ini mengandung pengertian bahwa pihak pengelola pendidikan senantiasa melakukan berbagai perbaikan dan peningkatan secara terus menerus untuk menjamin semua komponen penyelenggara pendidikan telah mencapai standar mutu yang telah ditetapkan.

$\begin{array}{ccr}\text { Konsep } & \text { ini } & \text { senantiasa } \\ \text { memperbaharui } & \text { proses } & \text { pendidikan }\end{array}$ berdasarkan kebutuhan dan tuntutan pelanggan atau pengguna jasa pendidikan. Jika tuntutan dan kebutuhan pelanggan berubah, maka pihak pengelola institusi pendidikan dengan sendirinya akan merubah mutu, serta selalu memperbaharui komponen produksi atau komponen-komponen yang ada dalam 
institusi pendidikan. Kedua, menentukan standar mutu (quality assurance). Paham ini digunakan untuk menetapkan standar-standar mutu dari semua komponen yang bekerja dalam proses produksi atau transformasi lulusan institusi pendidikan.

Standar mutu pendidikan misalnya dapat berupa pemilikan atau akuisisi kemampuan dasar pada masing-masing bidang pembelajaran, dan sesuai jenjang pendidikan yang ditempuh. Selain itu, pihak manajemen juga harus menentukan standar mutu materi kurikulum dan standar evaluasi yang akan dijadikan sebagai sebuah alat untuk mencapai standar kemampuan dasar. Standar mutu proses pembelajaran harus pula ditetapkan, dalam arti bahwa pihak manajemen perlu menetapkan standar mutu proses pembelajaran yang diharapkan dapat berdaya guna untuk mengoptimalkan proses produksi dan untuk melahirkan produk yang sesuai, yaitu yang menguasai.

Oleh karena itu, diantara upaya dan strategi yang dilakukan pemerintah dalam upaya peningkatan mutu pendidikan sehingga dapat menghasilkan pendidikan yang bermutu adalah menetapkan UU dan PP, diantaranya terdapat dalam GBHN, Undang-Undang Sistem Pendidikan Nasional No. 20 tahun 2003, PP No. 19 tahun 2005, dan lain sebagainya.

Dalam rangka menyahuti konsep peningkatan mutu pendidikan tersebut, hal ini terdapat dalam UUSPN Nomor 20 tahun 2003 disebutkan 6 kali kata-kata mutu. Selain itu juga dalam GBHN ada juga menggunakan istilah mutu. Hal ini disebutkan dalam bentuk pernyataan "Perwujudan sistem pendidikan nasional yang demokratis dan bermutu" dalam rangka mengembangkan kualitas manusia Indonesia (Alek, 2010).

Kemudian untuk mendukung pencapaian standar mutu tersebut didukung PP No. 19 tahun 2005 dan hal ini merupakan penjabaran dari UU No. 20 tahun 2003 sebagaimana menurut Tilaar bahwa adanya delapan standar pendidikan nasional, diantaranya 1) standar isi, 2) standar proses, 3) standar kompetensi lulusan, 4) standar pendidik dan tenaga kependidikan, 5) standar sarana dan prasarana, 6) standar pengelolaan, 7) standar pembiayaan, 8) standar penilaian pendidikan (HAR. Tilaar, 2006). Diantara yang delapan standar itu ada standar yang terpenting dan saling berkaitan erat dengan yang lain, yaitu standar pembiayaan. Pembiayaan ini merupakan motor penggerak standar-standar yang lain. Karenanya untuk meningkatkan mutu/kualitas sekolah atau lembaga pendidikan apapun nama dan jenisnya sangat membutuhkan pembiayaan sesuai dengan SBU dan SBK.

Dari hal ini dapat dipahami, dalam meningkatkan mutu pendidikan ada salah diantaranya yang harus terpenuhi dalam sistem pendidikan nasional menurut UU yaitu standar pembiayaan pendidikan. Standar pembiayaan pendidikan merupakan standar yang mengatur komponen dan besarnya biaya operasi satuan pendidikan yang berlaku selama satu tahun. Ada tiga macam biaya dalam standar ini, antara lain: a) biaya investasi satuan pendidikan, b) biaya personal, c) biaya operasi satuan pendidikan 
(Rusdiana, 2015).

Berkaitan dengan pembiayaan pendidikan ini, Fattah (Rida Fironika K, 2011) menjelaskan bahwa biaya yang rendah berpengaruh terhadap kualitas pendidikan di Sekolah Dasar dan proses pembelajaran serta kualitas outcomes yang dihasilkan menjadi tidak bermutu. Artinya ada korelasi yang positif antara besarnya biaya pendidikan terhadap peningkatan mutu pendidikan di berbagai lembaga pendidikan baik yang berada pada formal maupun non formal, baik yang berstatus negeri maupun swasta.

Oleh karena itu perencana pendidikan harus menggunakan sebaik mungkin sumber daya yang tersedia, mengawasi penggunaan sumber daya yang ada terhadap permintaan atas sumber daya tersebut, dan mensupport setiap argumen dengan analisa kuantitatif dengan menggunakan bantuan cost analysis pembiayaan tersebut.

UU No. 20 Tahun 2003 tentang Sistem Pendidikan Nasional Pasal 11 ayat 2 menyatakan bahwa Pemerintah Pusat dan Pemerintah Daerah wajib bersinergi untuk membantu dan bahkan menjamin tersedianya dana guna terselenggaranya pendidikan yang baik bagi setiap orang atau warga negara Indonesia yang berusia tujuh sampai lima belas tahun.

Dan pada pasal 12 , ayat 1 menyatakan setiap peserta didik pada setiap satuan pendidikan berhak mendapatkan beasiswa bagi yang berprestasi tetapi yang orangtuanya tidak mampu membiayai pendidikannya dan mendapatkan biaya pendidikan bagi mereka yang orangtuanya tidak mampu membiayai pendidikannya. Setiap peserta didik berkewajiban ikut menanggung biaya penyelenggaraan pendidikan, kecuali bagi peserta didik yang dibebaskan dari kewajiban tersebut sesuai dengan peraturan perundangundangan yang berlaku.

Kemudian berdasarkan UU No. 14 Tahun 2005 tentang Guru dan Dosen Pasal 13 bahwa Pemerintah dan Pemerintah Daerah wajib menyediakan anggaran untuk peningkatan kualifikasi akademik dan sertifikasi pendidik bagi guru dalam jabatan yang diangkat oleh satuan pendidikan yang diselenggarakan oleh pemerintah, pemerintah daerah, dan masyarakat (yayasan). sekolah negeri bermakna yaitu kalau satuan pendidikan yang dikelola oleh pemerintah baik pusat maupun pemerintah daerah seperti sekolah kedinasan dan sekolah yang berstaus negeri. Sedangkan swasta adalah sekolah yang statusnya dikelola oleh masyarakat. Ketentuan lebih lanjut mengenai anggaran untuk peningkatan kualifikasi akademik dan sertifikasi pendidik diatur dengan PP (peraturan pemerintah).

Oleh karena itu, keadaan keuangan atau pembiayaan dalam pendidikan merupakan salah satu sumber daya yang secara langsung menunjang efektifitas dan efisiensi pengelolaan pendidikan. Hal tersebut lebih terasa lagi dalam implementasi Manjemen Berbasis Sekolah (MBS), yang menuntut kemampuan lembaga pendidikan untuk merencanakan, melaksanakan dan mengevaluasi serta mempertanggung jawabkan pengelolaan dana secara transparan dan akuntabilitas kepada 
masyarakat dan pemerintah (Jamiludin Usman, 2016).

Hal ini penting terutama dalam rangka MBS (manajemen berbasis sekolah) di sekolah masing-masing, yang memberikan kewenangan kepada sekolah atau lembaga pendidikan untuk mengatur keuangan sekolahnya sesuai dengan standar yang berlaku. Karenanya menurut Siahaan (Amiruddin Siahaan, Khairuddin W, 2006), bahwa implikasi diterapkannya manajemen pendidikan berbasis sekolah adalah memberikan kewenangan kepada sekolah untuk mengelola dana sendiri. Pihak sekolah diberikan kewenangan untuk mencari dana dan menggunakannya berdasarkan prinsip akuntabilitas dan transaparansi. Setiap sekolah berupaya memperoleh dana dari masyarakat, baik masyarakat pengguna jasa sekolah (orang tua peserta didik) maupun anggota masyarakat dan dunia usaha, tetapi bersifat tidak mengikat.

Oleh karena itu Rida (Rida Fironika K, 2011) mengatakan bahwa model pembiayaan pendidikan memiliki dua sisi yaitu sisi pengalokasian dan sisi penghasilan. Seperti yang dikatakan oleh John S. Mrophet, pada dasarnya pembiayaan diklasifikasikan menjadi dua model, yaitu:

1. Flat Grand Model. Flat Grand Model menggunakan sistem distribusi dana, semua distrik atau Kabupaten/kota menerima jumlah dana yang sama untuk setiap muridnya tidak memperlihatkan perbedaan kemampuan daerah. Daerah yang sumber dayanya kaya raya dan daerah yang sumber daya alamnya tidak mendukung (miskin), untuk membiayai program pendidikan setiap menerima dana dengan jumlah yang sama dan dihitung biaya per siswa dalam 1 (satu) tahun yang direfleksikan sebagai kebutuhan yang bervariasi dalam unit biaya yang diberikan kepada sekolah.

2. Equalization Model. Equalization Model ini bertitik tolak pada ability to pay (kemampuan membayar) masyarakat. Masyarakat yang miskin tentu perlu menerima bantuan dana lebih serius dibanding dengan masyarakat yang incomenya lebih tinggi. Karena itu sekolah miskin akan memperoleh kesempatan sejajar dengan sekolah lainnya, artinya setiap daerah akan menerima jumlah dana yang berbeda tiap tahun tergantung bagaimana membagi sesuai kepada kemampuan daerah.

Dari paparan diatas dapat disimpulkan bahwa dalam mengelola suatu pembiayaan pendidikan diperlukan suatu konsep dan sistem perencanaan yang matang, agar mampu merumuskan sistem pembiayaan nasional pendidikan Indonesia dalam kerangka otonomi daerah.

Jika pengelolaan dan pendanaan bisa dipertanggungjawabkan, maka akuntabilitas sekolah/madrasah semakin kuat, dan berimplikasi kepada kredibilitas sekolah/madrasah dalam menyelenggarakan pendidikan (Amiruddin Siahaan, 2011). Ketika kredibilatas sudah tercapai berarti akan menuju peningkatan mutu pendidikan. 
Karenanya pengelolaan pendanaan pendidikan merupakan hal yang sangat penting menuju peningkatan mutu.

Kebanyakan berbagai sekolah maupun madrasah mengalami kesulitan dalam sarana dan prasarana, keterbatasan jumlah tenaga kependidikan dan kemampuan yang kurang memadai dalam memberikan imbalan kepada tenaga pendidik dan kependidikannya. Banyak tenaga pendidikan yang menjalankan tugas tidak sesuai dengan bidang keahlian dan pengalamannya di dunia pendidikan sehingga mengakibatkan pendidikan menjadi tidak maksimal dan tidak bermutu dan bahkan menjadi jauh tertinggal. Seperti adanya guru yang sekaligus menjadi tata usaha, dan tata usaha menjadi guru sehingga karena tidak terdapatnya guru yang berkualifikasi sesuai dengan kebutuhan, atau terdapatnya guru yang mengajar beberapa mata pelajaran di luar kualifikasi keilmuanya.

Biaya dalam dunia pendidikan memiliki cakupan luas, yaitu setiap jenis pengeluaran yang berkaitaan dengan penyelenggaraan pendidikan, baik dalam bentuk uang maupun barang dan jasa. Pembiayaan pendidikan merupakan proses dalam merencanakan, memperoleh, mengalokasikan dan mengelola biaya yang berkaitan dengan penyelenggaraan proses pendidikan yang akan dan sedang dijalankan.

Karenanya adapun macam-macam pembiayaan pendidikan ada tiga macam, yaitu a) biaya investasi satuan pendidikan, b) biaya personal, c) biaya operasi satuan pendidikan. Biaya investasi satuan pendidikan yaitu biaya penyediaan sarana dan prasarana, pengembangan sumber daya manusia, dan modal kerja tetap. Biaya personal adalah biaya pendidikan yang harus dikeluarkan oleh peserta didika untuk bisa mengikuti proses pembelajaran secara teratur dan berkelanjutan. Sedangkan biaya operasi satuan pendidikan meliputi: 1) gaji dan tunjangan pendidik dan tenaga kependidikan, 2) bahan dan peralatan pendidikan habis pakai, 3) biaya operasi pendidikan tidak langsung, seperti air, pemeliharaan sarana dan prasarana, pajak, asuransi, dan lain sebagainya (Rusdiana, 2015).

Sedangkan adapun yang menjadi sumber pembiayaan pendidikan pada sebuah lembaga pendidikan baik formal maupun non formal secara umum dapat dikelompokkan menjadi 2 (dua) sumber, yaitu yang berasal dari pemerintah dan orang tua/wali/mahasiswa dan masyarakat (Achmad Anwar Abidin, 2017).

1) Pemerintah. Pemerintah sebenarnya harus bertanggungjawab secara penuh dalam hal pemenuhan hak untuk memperoleh pendidikan bagi masyarakat, karena hal ini sebagai amanat dari UU yang sudah diatur dalam sebuah konstitusi negara kita Indonesia. Pemerintah dalam hal ini, baik pusat maupun daerah memiliki kewajiban yang sama dalam menetapkan anggaran dana pendidikan pada mata anggaran belaja negara baik APBN maupun APBD.

Adapun besaran biaya anggaran pendidikan yang ditetapkan pemerintah sesuai amanah UUD Negara Republik Indonesia pada pasal 31 ayat 4 tahun 1945 adalah sebesar $20 \%$ dari APBN dan APBD. Kalau untuk daerah provinsi dan 
pemerintah kabupaten/kota untuk pendidikan dasar baik jalur sekolah maupun non sekolah berdasarkan Peraturan Pemerintah (PP) dengan nomor 48 tahun 2008 tentang pendanaan pendidikan.

Secara khusus disebutkan bahwa dana pendidikan selain gaji pendidik dan biaya pendidikan kedinasan dialokasikan minimal $20 \%$ dari APBN pada sektor pendidikan dan minimal 20\% dari APBD. Gaji guru dan dosen yang diangkat oleh Pemerintah dialokasikan dalam APBN dan APBD. Partisipasi masyarakat dalam pendidikan berbasis masyarakat adalah dengan berperan serta dalam pengembangan, pelaksanaan kurikulum, dan evaluasi pendidikan, serta manajemen dan pendanaannya sesuai dengan standar nasional pendidikan. Dana penyelenggaraan pendidikan berbasis masyarakat dapat bersumber dari penyelenggara, masyarakat, Pemerintah, Pemerintah Daerah dan atau sumber lain yang tidak bertentangan dengan peraturan perundang-undangan yang berlaku.

2) Orang tua/wali/mahasiswa dan masyarakat. Adapun sumber pembiayaan pendidikan selain dari pemerintah adalah orang tua/wali/mahasiswa dan masyarakat ini biasanya berupa Sumbangan Pembinaan Pendidikan (SPP) yang kalau dulu BP3, uang pembangunan, dan lain sebagainya berdasarkan ketentuan yang ada.

\section{Implikasi Pembiayaan Pendidikan dan Peningkatan Mutu}

Sebagai upaya dalam peningkatan mutu dalam pendidikan, pembiayaan dan pendanaan pendidikan adalah hal terpenting, karenanya pemerintah memberlakukan sebuah standar yang mengharuskan seluruh pengelola satuan pendidikan mencari dan mendistribusiakan seluruh dana sesuai dengan aturan yang berlaku.

Meskipun adanya kebijakan yang dilakukan oleh pemerintah tentang peningkatan anggaran dengan mengalokasikan dana pendidikan 20\%, baik dari APBN maupun APBD. Hal ini secara ekspelisit sebenarnya untuk memperbaiki mutu pendidikan kita yang berada di Indonesia. Dana pendidikan yang $20 \%$ tersebut haruslah digunakan secara maksimal sesuai dengan aturan dan perundang-undangan yang ada.

Namun demikian, penggunaan dana pendidikan yang digelontorkan oleh pemerintah pusat maupun daerah tersebut harus juga dilakukan dengan menggunakan prinsip transparan dan akuntabilitas.

\section{SIMPULAN}

Berdasarkan uraian di atas tentang pembiayaan pendidikan dan peningkatan mutu dapat diambil kesimpulan, antara lain: Peningkatan mutu pendidikan merupakan hal terpenting dan utama. Untuk tercapainya pendidikan bermutu dibutuhkan pembiayaan pendidikan sesuai dengan standar yang ditetapkan pemerintah. Pembiayaan pendidikan harus dilakukan dengan prinsip transparansi dan akuntabilitas sesuai dengan peraturan perundang-undangan yang berlaku. Hal ini dilakukan untuk meningkatan kredibilitas sekolah/madrasah, sebagai upaya peningkatan mutu dalam pendidikan. Terdapat tiga macam biaya 
dalam standar pembiayaan pendidikan, antara lain: a) biaya investasi satuan pendidikan, b) biaya personal, c) biaya operasi satuan pendidikan. Sehingga dalam pengelolaan pendidikan, sistem pendanaan inilah yang harus dikelola dengan baik sesuai dengan SBU (standar biaya umum) dan SBK (standar biaya khusus) sebagaimana yang telah ditetapkan oleh Pemerintah.

\section{DAFTAR PUSTAKA}

Achmad Anwar Abidin. (2017). Manajemen Pembiayaan Pendidikan Tinggi Dalam Upaya Peningkatan Mutu (Studi Kasus Pada Perguruan Tinggi Swasta Menengah di Surabaya). Jurnal Penjaminan Mutu, 3(1), 8799.

https://doi.org/http://dx.doi.org/10.25 078/jpm.v3i1.95

Alek. (2010). Menyoal Konsep Mutu dalam Kebijakan Pendidikan. In Sam M. Chan (Ed.), Isu-isu kritis Kebijakan Pendidikan Era Otonomi Daerah (1st ed., p. 6).

Alex. (2010). Isu-Isu Kritis Kebijakan Pendidikan Era Otonomi Daerah (M. C. dan E. Sam (ed.); I).

Amiruddin Siahaan, Khairuddin W, I. N. (2006). Manajemen Pendidikan Berbasis Sekolah (1st ed.). Quantum Teaching (Ciputat Press Group).

Amiruddin Siahaan, W. L. Z. (2011). Paradigma Baru Administrasi Pendidikan (Peningkatan Kualitas Manajemen SDM Satuan Pendidikan) (Syahrum (ed.); 2nd ed.). Citapustaka Media Perintis.

HAR. Tilaar. (2006). Standar Nasional Pendidikan (1st ed.). PT. Rineka Cipta.

Jamiludin Usman. (2016). Urgensi Manajemen PRGENSI Pendidikan Madrasah. Jurnal Tadris, 11(2). https://doi.org/-

Marsus Suti. (2011). Strategi Peningkatan Mutu di Era Otonomi Pendidikan. Jurnal Medtek, 3(2), 1-6. https://d1wqtxts1xzle7.cloudfront. net/35942976/Jurnal_Pak_Marsus _Suti.pdf

Rida Fironika K. (2011). Pembiyaan Pendidikan di Indonesia. Jurnal Ilmiah Pendidikan Dasar, 26(1), 43-63.

http://research.unissula.ac.id/file/p ublikasi/211312012/3602artikel_R ida.pdf

Rusdiana. (2015). Kebijakan Pendidikan (Dari Filosofi ke Implementasi) (1st ed.). CV. Pustaka Setia.

Ulpha Lisni Azhari, D. A. K. (2016). Manajemen Pembiayaan Pendidikan, Fasilitas Pembelajaran dan Mutu Sekolah. Jurnal Administrasi Pendidikan, 23(2), 27-34.

https://doi.org/https://doi.org/10.17 509/jap.v23i2.5631

Veitzhal Rivai, dkk. (2009). Education Manajemen (Analisis Teori dan Praktek) (1st ed.). PT. Rajagrafindo Persada. 